\title{
EFFECT OF INTRINSIC AND EXTRINSIC MOTIVATION ON EMPLOYEE PRODUCTIVITY: CASE OF LE GRANDE HOTEL PECATU
}

\author{
I Nyoman Gede Astina, Dewi Ambarwati. \\ STPBI - The International Bali Tourism Institute
}

\begin{abstract}
This study aimed to determine the effect of intrinsic and extrinsic motivation on employeeproductivity at Le Grande Hotel Pecatu. The independent variables studied were Intrinsic Motivation (X1) and Extrinsic Motivation (X2) with the dependent variable is the Work Productivity (Y). Data sampling used questionnaires to 120 respondents, while sampling used simple random sampling method. The tests used to test the research instrument are in the form of test validity and reliability testing. Hypothesis testing used the F test and t test. The results showed that multiple regression analysis based on the results obtained by the equation: $Y=2,112+0,340 X 1+0,418 X 2$. Based on the results of the most dominant variable affecting the Work Productivity Extrinsic motivation is variable with a regression coefficient of 0.418. Hypothesis testing using the F test and t test showed that simultaneous or partially intrinsic and extrinsic motivation have significant effect on employee productivity at Hotel Le Grande.
\end{abstract}

Keywords: Intrinsic Motivation, Extrinsic Motivation, Work Productivity

\section{Introduction}

Bali as one of the destinations most visited by tourists both from abroad and the archipelago, in the people's daily life applying cosmological concept of Tri Hita Karana. Tri Hita Karana emphasizes three human relationships in this life including relationships with fellow human beings, the relationship with the surrounding nature, and the relationship with God. Bali, with the concept of Tri Hita Karana offers a memorable holiday moments, combining the natural beauty, culture and harmonious spiritual life.

In order to survive and thrive, companies engaged in accommodation in Bali should be able to develop and cultivate a variety of available resources, such as capital, materials and machines to achieve the goals. Besides that, companies also need to develop human resources which are employees. Employees are the seller of services (thoughts and energy) and receive compensation in the amount had been determined previously. They are obliged and bound to do the assigned work and shall be compensated in accordance with the agreement. (Hasibuan, 2000: 12)

Motivation is something that causes a boost in a person to do something in order to achieve the goals that have been set previously. Furthermore, productivity is the ratio between the output (physical unity, form and value) and input (labor) of the overall resource used. Because everyone has a different 
motivation, motivation can come from inside (intrinsic) or external (extrinsic) then a manager should be able to know which motivation is most suitable for the employees, so that employees are motivated and productivity will increase in order to achieve company goals.

Le Grande Hotel is located in the area of Pecatu Indah Resort. Le Grande Hotel should be able to compete with hotels, especially with hotels in the area. Hotel Le Grande has employed as many as 172 employees. Some forms of motivation given to employees include basic salary; basic salary is given every month based on the employee's job title and years of service . Leave is as many as 12 days in one year. Festive Allowance or Tunjangan Hari Raya (THR) is given to each employee as much as one basic salary. Service charge money is distributed evenly to all employees every month. Health benefit, meal, transport allowance, and award for the best employee every month (employee of the month). For the employee of the month in addition to getting an award certificate, also gets a cash bonus. Management also seeks to create a comfortable working environment for employees and give promotion for outstanding employee at his/her field. Even though management has provided motivation but there are some employees who are late for work, complaints from employees about poorly performing colleagues and rest for too long.

Thus the authors assume that the effect of intrinsic and extrinsic motivation to improve employees' productivity need to be further studied.

\section{Research Questions}

R1. Do intrinsic and extrinsic motivations have influence on employees productivity?

$\mathrm{R} 2$. Which motivation is more dominant in affecting employees productivity?

\section{Literature Review}

Resky Astrini (2012) conducted a study entitled Effect of Intrinsic Motivation and Extrinsic Motivation Against Employees Work Productivity at the Makasar State Property Office and Auction. From results of the study it was found that intrinsic and extrinsic motivation effect on employees' productivity. In addition, it was also found that intrinsic motivation was more dominant to effect on employees' productivity than extrinsic motivation. Furthermore, research by Nurul Utami Dwi (2014) with the title Influence of Work Discipline and Work Motivation Against Employees Productivity At Sahid Jaya Hotel Makassar. From these studies it was found that the work discipline and work motivation significantly influence employees' productivity at Sahid Jaya Hotel Makasar. This study discusses the effect of intrinsic motivation and extrinsic motivation to work productivity.

\section{Motivation}

The ability of a person is determined by the qualifications he has, among other things such as education, experience, and personal traits, while motivation is influenced by something within oneself and other things from the outside. 
Motivation exists in a person, often called motive. Liang Gie (in Manullang, 2006: 165) argues that the motive or inner drive is a drive that becomes the base of someone doing something. While the external drive should be inflicted by leaders, so leaders must choose the means or instruments in accordance with the others. Handoko (2012: 252) argues that motivation can be defined as a state in the person's personality who encourages the individual desire to undertake certain activities in order to achieve goals. Wexley \& Yukl (in Sutrisno, 2009: 110), imposes limits on motivation as the process by which behavior is energized and directed. Motivation definition as proposed by Wexley \& Yukl is a gift or reward or motive infliction. So motivation is something that raises the spirit or work boost.

Bernard Barelson \& Gary A. Stoner (in Siswanto, 2005) defines motivation as all those inner striving condition variously described as wishes, desires, needs, drivers and the like. Motivation can be defined as a state of the human psyche and the mental attitude that gives a boost of energy towards activities, and leads or channel behavior towards achieving the needs that give satisfaction or reducing imbalances.

Schemerhorn, J.R. (in Wijayanto, 2012: 148) defines motivation as a force from within the individual that affect the level, direction, and persistence in showing the work effort. Manullang (2006: 166) work motivation is something that causes a push or morale. In other words, motivation is a morale booster.

Gorda (2004: 167) motivation is a series of boost intentionally formulated by the leaders of the company indicated to employees that they are willingly perform certain behaviors that affect the performance improvement in achieving corporate objectives that have been set previously.

From the definition of motivation according to the experts above, it can be concluded that motivation is a need encouragement and desires of the individual which is directed to goals to obtain what they need.

\section{Objectives and Motivation Tools}

Hasibuan (2000: 146) the purpose of motivation is as follows:

a. To improve employees morale and job satisfaction.

b. To increase employee productivity.

c. To maintain the stability of the company's employees.

d. To increase employees discipline.

e. To streamline the employees procurement.

f. To create good atmosphere and a working relationship.

g. To create loyalty, creativity, and employees participation.

$h$. To increase the level of employees welfare.

i. To enhance employees' sense of responsibility towards their duties.

j. To improve the efficiency of the use of tools and raw materials.

According Hasibuan (2000: 149) motivational tools (stimulator power) given to subordinates can be: 
a. Material incentive

Material incentive is motivation (stimulator power) that is materially as an achievement reward given to employees. Things included as material incentive is in the form of money and goods.

b. Nonmaterial incentive

Nonmaterial incentive is motivation (stimulator power) that is nonmaterial. Things included as nonmaterial incentive are proper placement, secured job, awards certificate, decorations, fair treatment, and the like.

\section{Types and Process of Motivation}

The types of motivation according Hasibuan (2000: 150) is positive and negative motivation. The use of positive motivation and negative motivation should be precise and balanced in order to improve employees' morale. The explanation of positive motivation and negative motivation is as follows:

a. Positive Motivation

Positive motivation, means that manager motivates (stimulates) subordinates by giving gifts to those who excel above standardized achievement. With positive motivation subordinates' morale will increase because humans are generally happy to accept the good things.

b. Negative Motivation

Negative motivation, means the manager motivates (stimulates) subordinates by imposing penalties if performance is less than the standard. With this negative motivation subordinates' work spirit will increase in short term because of fear of punishment, but for the long term the result is less good.

While the processes of motivation according Hasibuan (in Hartatik, 2014: 169) is as follows:

a. Aim

In the process of motivation, the organization's goals need to be set in advance. After that, then employees are motivated towards the goal.

b. Knowing the Interests

The important factors in the process of motivation is a to know the employees' desire and not only look from the point of view of the leader or company's interest alone.

c. Effective Communication

In the process of motivation we must do good communication with subordinates. Subordinates must know what will be gained (eg incentives) and the conditions that must be fulfilled so that such incentives can be obtained.

d. Integration of Purpose

The process of motivation is required to unify the organization's goals and interests of employees. The purpose of the organization is a complex needs, i.e. to make a profit as well as the expansion of the company. While the individual goal is to meet the needs and satisfaction. So, organizational and individual goals should be unified. Therefore, it is important to have adjustments on motivation.

e. Facilities

Manager is important to provide assistance to organizations and individuals employees facility who will support the smooth work execution. 


\section{f. Team Work}

Managers must establish a well-coordinated team work well, so that it can achieve its goals. The existence of team work is very important, because usually there are a lot of parts in a company.

From some description above it can be concluded that there are two types of motivations which are positive motivation and negative motivation. Besides that, motivational processes such as purpose, knowing the interests, effective communication, and integration of purpose, facilities and team work.

\section{From Herzberg's Two Factor Theory.}

Based on research conducted by Herzberg and his colleagues it was found two groups of factors that affect a person's work in organization. Factors that causes job satisfaction has the effect of driving for work performance and morale, and the factors that cause job dissatisfaction has a negative influence.

Based on the results of their research, distinguishing between what they called "motivators" or "gratification" and the factors of maintenance or the so-called "hygiene factors". Motivator has influence to improve achievement or job satisfaction. Maintenance factor (hygiene factors), prevent decline in morale or efficiency, and despite these factors can not motivate, but can lead to dissatisfaction or lower labor productivity. Repairs to the factors of maintenance as a negative factor (extrinsic) can reduce or eliminate job dissatisfaction and avoid the problem, but will not be used to motivate subordinates. Only the positive factors were the "motivators" (intrinsic), which can motivate the employees to carry out the wishes of the manager.

According to Herzberg's theory of two factors cited in (Gorda, 2004: 176) that motivates employees to be willing to work hard towards achieving the company's objectives, namely:

a. Hygiene Factors, which include policy and administration, supervision, interpersonal relationships with superiors, working conditions, salary. (Extrinsic)

b. Motivation Factors, which include the success, recognition, work itself, responsibility, development. (Intrinsic)

\section{Achievement Theory of McClelland.}

David McClelland suggested that there is a positive correlation between the need for achievement with achievement and successful implementation.

McClelland (in Handoko, 2012: 262) also found that these achievements need to be developed in adults. Achievement-oriented people have certain characteristics that can be developed, namely:

a. Like worth-taking risks as a function of skill, not chance, like challenge, and want responsibility personal responsibility for the outcomes achieved.

b. Have a tendency to set worthy of achievement goals and face the risk that has been taken into account.

c. Having a strong need for feedback on what he/ she has done.

d. Have skills in long-term planning and have organizational abilities. 


\section{Hope Theory (Expectancy theory)}

Expectancy theory states that the employee's behavior can be explained by the fact: employees determine in advance whether their behavior can be implemented and the expected value as alternative outcomes from the behavior. According to Victor Vroom (Handoko, 2012: 263), known as the Vroom theory of value expectations, people are motivated to work if they:

a. Expect increased efforts will lead to certain rewards.

b. Assess rewards as a result of their efforts.

\section{Theory of Behavior Formation (Reinforcement theory)}

BF Skinner (Handoko, 2012: 264) argues that the behavior followed by satisfying consequences tend to be repeated, whereas behavior followed by punishments tend to be not repeated. Thus the behavior of individuals in future can be predicted or learned from the experience of the previous time.

According to BF Skinner (in Handoko, 2012: 265) there are four techniques you can use to change the behaviour of subordinate managers, namely:

a. Positive Reinforcement, such as food or drink that satisfies the biological needs. Or rewards in the form of gifts, promotion and money.

b. Negative reinforcement, where individuals will learn the behaviors that bring unpleasant consequences, and then avoid such behavior in the future (avoidance learning).

c. Termination, carried out with elimination of reinforcement.

d. Punishment, manager alters employees behavior that is not appropriate with the provision of negative consequences.

W Clay Hammer (in Handoko, 2012: 265) has identified six guidelines for the use of the techniques of behavior formation, or so-called theory of learning (learning theory), namely:

a. Do not give the same reward to everyone

b. Note that failure to respond can also change behavior.

c. Tell employees about what should be done to get the award.

d. Tell employees about what was done wrong.

e. Do not give punishment in front of other employees.

f. Act fairly.

\section{The Theory of Porter-Lawler}

Porter-Lawler theory is a theory of expectation of motivation with the orientation version of future, and also stressed the anticipation of responses or results. The manager depends mainly on the hope of the future, and not the usual experience of the past. This expectation model presents a number of implications for managers on how to motivate subordinates and also the implications for the organization.

Nadler and Lawler (in Handoko, 2012: 266-267) the implications of the model for managers includes:

a. The reward in accordance with the needs of subordinates.

b. Determination of the desired achievement.

c. Making the achievement levels that can be achieved.

d. Linking rewards with achievements.

e. Analysing the factors that are contrary to the effectiveness of the award. 
f. Determination of sufficient or adequate appreciation.

While the implications for the organization includes:

a. Organizational reward system should be designed to motivate the desired behavior.

b. The work itself can be made as an intrinsic award.

c. Direct superiors have an important role in the process of motivation.

\section{Equity Theory}

This theory suggests that, people will always tend to compare between the input they provide to the job in the form of education, experience, practice and effort with results (rewards) which they have received as well as they compare the rewards received by other employees with him for the same job. (Handoko, 2012: 267)

\section{Intrinsic Motivation and Extrinsic Motivation}

Intrinsic motivation is the motivation that drives a person to perform which originates within the individual, which is better known by motivators or motivational factors. According to Herzberg cited by Manullang (2006: 178), factors that act as motivators for employees include: Achievement (Success), recognition (awards), Work itself, Responsibility and Advancement (Development).

Extrinsic motivation is a motivation that comes from outside ourselves that determines a person's behavior in a person's life, known as the theory of hygiene factor. According to Herzberg cited by Manullang (2006: 179), which is classified as a hygiene factor, among others, are the following: Technical supervision, Interpersonal relations, Policy and administration, Wages (Salaries and Working condition)

\section{Productivity}

Productivity is generally defined as the relationship between outputs (goods or services) with inputs (labor, material, money). Productivity is the measurement of productive efficiency. It is a measure of the ratio between output and input. Input is often limited by manpower, while the output measured in all physical units, form and value. (Edy Sutrisno, 2009: 99)

\section{Measurement and Assessment Work Productivity Benefits}

According Muchdarsah (in Hartatik, 2014: 215) to measure the productivity of each employee, there should be a measure of labor productivity. Labor productivity measurement system according to the physical income per person or per hour of work people can be widely accepted by using the method of measurement of labor time (hour, day, year). Measurement is converted into units of workers which is defined as the amount of work done in one hour by workers who work according to certain standards. Both of which are related to labor itself as well as other factors. 
Sedarmayanti (2011: 228-232) factors that affect work productivity, including:

a. Mental attitude, such as motivation, work discipline, work ethic.

b. Education.

In general, people who have a higher education will have greater insight, especially the appreciation of the importance of productivity.

c. Skills.

On certain aspects where more skilled the employees are, it will be able to work and use the work facilities properly.

d. Management.

e. Pancasila Industrial Relations.

f. Income level.

g. Nutrition and health

h. Social Security

i. Means of production

j. Technology

k.Opportunities for achievement

Work Productivity Indicator

According Simamora (in Hartatik, 2014: 218-219) indicators of labor productivity, among others:
a. High absence rate.
b. The rate Of Yield.
c. Quality produced.
d. The Error Rate.
e. Time required. 


\section{Conceptual Framework}

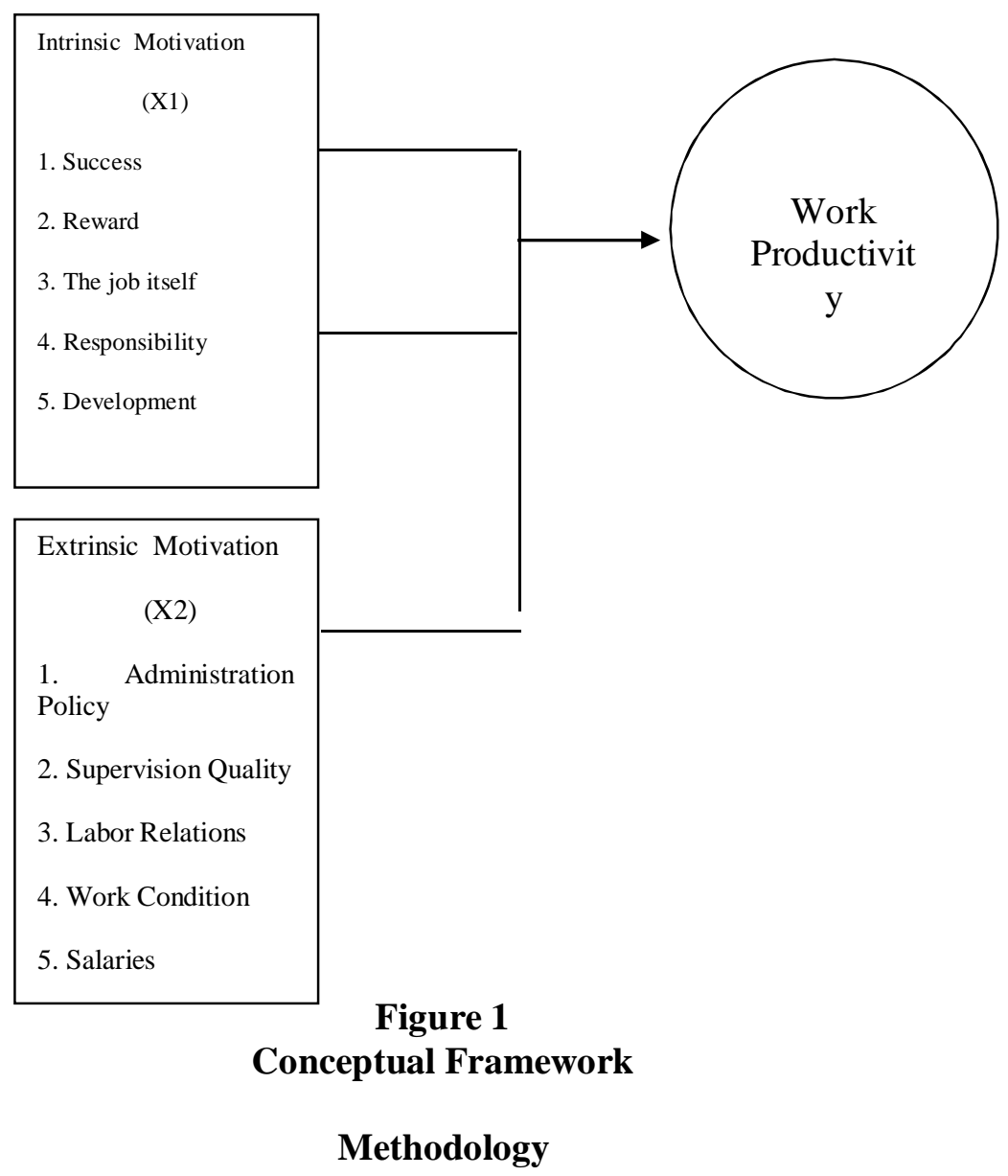

This study is quantitative. The existing variables in this study are:

a. Independent variables are (X1) Intrinsic Motivation and (X2) Extrinsic motivation.

b. Dependent variable (Y) labor productivity.

Using random sampling techniques (simple random sampling) as many as 120 responded.

The primary data used included a questionnaire about the effect of intrinsic and extrinsic motivation on employee productivity.

Data analysis techniques using multiple linear regression

\section{Results and Discussion}

The form of intrinsic and extrinsic motivation provided by Hotel Le Grande to employees are: 
a. Intrinsic motivation: give praise and awards (employee of the month) to employees who successfully work well and above the standard, send some employees to follow the employee development and training programs in accordance with their field, recommends and offers promotion or to increase employee positions.

b. Extrinsic motivation: good supervision techniques, good communication among employees and between subordinates to superiors, clear policies made in writing and published, giving a basic salary in accordance with the standards of the UMK (City Minimum Wage), giving service charge money, employee meal, giving festive allowance in accordance with each employee's festive day, the provision of health care, and provision of transportation allowance.

\section{Hypothesis Test Results}

Multiple linear regression analysis used in this study with the aim to prove hypotheses about the effects of intrinsic motivation variable (X1) and extrinsic motivation (X2) partially or together on employee productivity (Y).

a. Significant Simultaneous Test (Statistic Test F)

The results obtained $\mathrm{F}$ count (44.470)> F table (3.07) with a significance level $(0.000)<\alpha(0.05)$, so that $\mathrm{H} 0$ was rejected and $\mathrm{H} 1$ was accepted. Therefore, it can be concluded that intrinsic motivation variable (X1) and extrinsic motivation variable (X2) simultaneously or jointly influence significant effect on work productivity (Y).

b. Significant Partial test ( $t$ test)

The $t$ test showed that the constant of 2.112. Intrinsic motivation (X1) has a regression coefficient of 0.340 and t-test value of 3.477 with significance 0.001 $<0,05$. Thus partially variable intrinsic motivation (X1) significantly affect labor productivity $(\mathrm{Y})$. In addition to the $\mathrm{t}$ test also showed that the extrinsic motivation (X2) has a regression coefficient of 0.418 and t-test value of 4.386 with significance $0.000<0.05$. Then partially extrinsic motivation variable (X2) significantly affect labor productivity $(\mathrm{Y})$. From the test results SPSS t-test intrinsic motivation (X1) of 3.477 and extrinsic motivation (X2) of 4.386>t-table is (1.98), so that Ho was refused and H1 was accepted. The more dominant variable is extrinsic motivation variable $(\mathrm{X} 2)$ on work productivity $(\mathrm{Y})$. This is indicated by the value of regression coefficient of extrinsic motivation (X2) of $0.418>$ regression coefficient intrinsic motivation $(\mathrm{X} 1)$ amounting to 0.340 .

\section{A More Dominant Motivation Influenced towards Employees Productivity at Le Grande Hotel}

It is known that the effect of extrinsic motivation on employees' work productivity is more dominant or higher compared to intrinsic motivation. The relation of extrinsic motivation on employees productivity is by $41.8 \%$. While intrinsic motivation effect on employee productivity by $34 \%$. This is in accordance with the theory presented by Herzberg (Handoko, 2012: 259) states that the factors of maintenance (the Extrinsic) prevent the decline of morale or efficiency, and despite these factors cannot motivate, but can lead to job dissatisfaction or decreased productivity. Extrinsic motivation consists of administration policy, quality supervision, labor relations, working conditions and salaries. 


\section{Conclusions}

It is known that the F-count (44.470)> F-table (3.07) with a significance level $(0.000)<\alpha(0.05)$. So that intrinsic motivation and extrinsic motivation simultaneously / together have a significant effect on employee productivity at Hotel Le Grande.

From these results, extrinsic motivation has a predominant influence rather than intrinsic motivation on employee productivity at Le Grande Hotel.

\section{Suggestion}

The survey results revealed that extrinsic motivation is more dominant than intrinsic motivation. Therefore the management of Le Grande Hotel is expected to improve the provision of intrinsic motivation.

From the results of the study also is known that the effect of the motivation provision whether the intrinsic motivation or extrinsic motivation have positive effect on employees' work productivity. Therefore the company is expected to maintain the motivation system, both intrinsic motivation and extrinsic motivation, because it proved that the administration of intrinsic motivation and extrinsic motivation impact on employees productivity.

\section{References}

Astrini. R. (2012). Pengaruh Motivasi Intrinsik dan Motivasi Ekstrinsik Terhadap Produktivitas Kerja Pegawai Pada Kantor Pelayanan Kekayaan Negara dan Lelang. Makasar: Universitas Hasanuddin

Dessler, G. (2008). Manajemen Sumber Daya Manusia Jilid 1. Jakarta: Indeks

Gorda, I.G.N. (2014). Manajemen Sumber Daya Manusia. Denpasar: Astabrata

Handoko, T.H. 2(012). Manajemen Edisi 2. Yogyakarta: BPFE

Hartatik, I.P. (2014). Mengembangkan Sumber Daya Manusia. Yogyakarta: Laksana

Hasibuan, M.S.P. (2000). Manajemen Sumber Daya Manusia. Jakarta: PT. Bumi Akasara

Manullang, (2006).Manajemen Personalia. Yogyakarta: Gadjah Mada University Press

Manullang, 2005.Dasar-Dasar Manajemen. Yogyakarta: Gadjah Mada University Press

Pantiyasa, I.W. 2013. Metodologi Penelitian. Yogyakarta: ANDI

Sedarmayanti. (2009). Sumberdaya Manusia dan Produktivitas Kerja. Bandung: CV. Mandar Maju

Sedarmayanti. (2011). Tata Kerja dan Produktivitas Kerja. Bandung: CV. Manda Maju

Siswanto, H.B. (2005). Pengantar Manajemen. Jakarta: Bumi Aksara

Sugiyono. (2013). Metode Penelitian Kuantitatif Kualitatif dan R\&D. Bandung: Alfabeta

Sutrsino, E. (2009). Manajemen Sumber Daya Manusia. Jakarta: Kencana 
Utami, N.D. (2014). Pengaruh Disiplin Kerja dan Motivasi Kerja Terhadap Produktivitas Kerja Karyawan Pada Hotel Sahid Jaya Makasar. Makasar: Universitas Hasanuddin

Wijayanto, D. (2012). Pengantar Manajemen. Jakarta: PT. Gramedia Pustaka Utama

Wikipedia. (2011). Pariwisata di Indonesia.

https://id.wikipedia.org/wiki/Pariwisata_di_Indonesia. 